\title{
RESPIGADORAS MODERNAS E PRODUÇÃO DA EXISTÊNCIA NO AGRONEGÓCIO CANAVIEIRO: A (DES)REA̧LIZAÇÃO NO TRABALHO DE BITUQUEIRAS
}

\author{
Modern Gleaners and the Production of Existence: gleaner work in the ethanol industry
}

\begin{abstract}
RESUMO
Esta pesquisa analisa as estratégias de defesa individuais e coletivas (DEJOURS) mobilizadas por trabalhadoras do agronegócio para lidar com o estranhamento do trabalho (ANTUNES) e os mecanismos sociais de habituação do trabalhador (BRAVERMAN). A partir dessa tríade conceitual busca-se responder à seguinte questão: como as bituqueiras mobilizam defesas na realização de um trabalho que é rigidamente organizado e precário? Para a coleta de dados utilizou-se a técnica de entrevistas semiestruturadas com nove trabalhadoras que exercem o trabalho de bituqueiras. O método de análise de conteúdo foi empregado na análise das entrevistas. Os resultados mostram que essas trabalhadoras mobilizam diferentes estratégias individuais que se tornam a base para um sistema social de defesa: (1) medo da demissão devido às poucas opções de trabalho locais para a mulher com baixa qualificação e à necessidade de sobrevivência; (2) ansiedade frente aos riscos gerados por uma atividade laboral que causa sofrimento físico e mental; (3) angústia e raiva ao lidar com desigualdades nas questões de gênero; (4) valorização do prazer de adquirir produtos vis-à-vis o impossível prazer de um trabalho libertador; e (5) busca de sentido para a sua existência vis-à-vis a crueldade da estigmatização e o "nojo social". O artigo mostra o potencial da tríade conceitual utilizada na pesquisa para uma compreensão das relações interníveis: estratégias de defesa dos trabalhadores, sistemas coletivos de defesa, processos da gestão empresarial e processos socioeconômicos.
\end{abstract}

Jacquelaine Florindo Borges

Universidade Federal de Uberlândia

jacborges@ufu.br

Alessandro Gomes Enoque

Universidade Federal de Uberlândia

alessandroenoque@ufu.br

Alex Fernando Borges

Universidade Federal de Uberlândia

alexfborges@gmail.com

Recebido em: 15/09/2016. Aprovado em: 26/04/2017

Avaliado pelo sistema double blind review

Avaliador cientifico: Daniel Carvalho de Rezende

DOI: 10.21714/2238-68902017v19n1p031

\begin{abstract}
This research analyzes the individual and collective defense strategies (DEJOURS) mobilized by agribusiness workers to deal with the estrangement of work (ANTUNES) and the social mechanisms of worker habituation (BRAVERMAN). This conceptual triad seeks to answer the following question: how do the individuals mobilize defenses in the performance of a work that is rigidly organized and precarious? For data collection, the technique of semi-structured interviews was applied to nine workers who perform the work of "bituqueiras". The content analysis method was used in the interview analysis. The results show that these workers mobilize different strategies that become the basis for a social defense system: (1) fear of dismissal due to the few local job options for women with low qualifications and the need for survival; (2) anxiety about the risks generated by a work activity that causes physical and mental suffering; (3) anguish and anger in dealing with inequalities in gender issues; (4) valuing the pleasure of acquiring products vis-à-vis the impossible pleasure of a liberating work; and (5) the search for meaning for their existence vis-à-vis the cruelty of stigmatization and "social disgust". This article shows the potential of the conceptual triad used in the research for an understanding of internal relations: workers' defense strategies, collective defense systems, business management processes and socioeconomic processes.
\end{abstract}

Palavras-chave: Estranhamento, Habituação, Degradação, Cana-de-açúcar.

Keywords: Work Degradation, Work Estrangement, Worker Habituation, Sugar Cane.

\section{INTRODUÇÃO}

Nos últimos anos, o aumento da produção da cana-de-açúcar no Brasil está associado com exploração e condições precárias de trabalho (BOCCHINI, 2011). Desde 2007, a utilização da cana-de-açúcar na produção de etanol exacerbou a prática de trabalho escravo, sendo o agronegócio o setor da economia que concentra a maioria dos casos (SENADO FEDERAL, 2011). Em relatório de 2005, dados da Organização Internacional do Trabalho (OIT) indicam que essa nova escravidão difere da antiga, visto que os escravos de hoje são vistos como totalmente descartáveis, devido ao baixo custo de recrutamento da mão de obra e o grande contingente de 
trabalhadores desempregados, o que possibilita lucros elevados. A manutenção da ordem e o controle dessa mão de obra é feita por meio do uso de ameaças, violência psicológica, coerção física, punições exemplares e até assassinatos. Os problemas com o trabalho escravo estão presentes em diferentes países, independente do grau de desenvolvimento (SENADO FEDERAL, 2011).

Além das condições degradantes, a exploração de milhões de trabalhadores na agricultura capitalista ocorre por meio dos problemas advindos do desemprego estrutural, mecanização acelerada que vem reduzindo o número de empregos e colocando um grande número de trabalhadores em uma população de desempregados, com função de um exército de reserva; e do desemprego sazonal, oscilação do número de emprego próprio de cada produção agrícola, o que implica estar empregado por um curto período de tempo. No primeiro caso, desempregados que buscam desesperadamente por trabalho são obrigados a aceitar salários baixíssimos e condições de trabalho desumanas, e, no segundo caso, o padrão de vida dos trabalhadores agrícolas é constantemente afetado, por esses só conseguirem trabalho em um curto período de tempo (BURBACH; FLYNN, 1982).

$\mathrm{Na}$ produção de commodities, produtos de exportação do agronegócio, o arcaico e o moderno se manifestam de maneira cruel em relações de trabalho baseadas em relações sociais arcaicas de servilismo e de submissão aliadas ao cálculo econômico e à representatividade desses produtos no balanço das empresas e na balança comercial do país (SENADO FEDERAL, 2011). O crescimento da produção e o aumento da produtividade na produção de cana não podem ser explicados sem a degradação das condições de trabalho e a exploração do trabalhador dos canaviais (ROSA; NAVARRO, 2014; SILVA, 2011). A precarização absoluta do trabalho em condições de escravidão no século XXI também se alimenta de problemas sociais, dentre eles o analfabetismo, a pobreza, o desemprego e de interesses políticos e econômicos que impedem e retardam a fiscalização. Essa precarização, presente no trabalho em canaviais, ainda gera outros problemas para os trabalhadores e a sociedade devido às condições de trabalho: falta de cuidados com a saúde, adoecimentos relacionados ao uso do corpo e movimentos repetitivos, problemas respiratórios, diferentes formas de pressão devido às relações de poder fortemente desiguais, baixas condições de alimentação e higiene, desrespeito aos direitos trabalhistas, acidentes de trabalho, etc. Em tal contexto, estudos acadêmicos têm se dirigido para a denúncia de tais condições (ALVES, 2006; LOUREIRO, 1981; MACIEL et al. 2011; SILVA, 2011).

Especificamente sobre o trabalho de bituqueiras, conhecidas como as faxineiras do canavial, segundo Silva (2011), destacam-se as seguintes características: (a) é um trabalho realizado por mulheres, preferidas pelos empreiteiros para executar a função, por conta do estereótipo de serem mais cuidadosas; (b) após o corte da cana, para evitar a proliferação de bactérias que podem comprometer a rebrota da cana, é preciso retirar o toco, caso a cana não tenha sido cortada rente ao chão; (c) os tocos ficam porque os cortadores de cana, afetados pela curvatura do corpo e pela jornada de trabalho, conseguem burlar os supervisores; (d) por comprometer a rebrota da cana ou gerar a proliferação de bactérias, a retirada dos tocos ou bitucas é uma forma de evitar o aumento dos custos ou a redução da produtividade da próxima safra; (e) todavia, apesar da importância do trabalho de bituqueira para a recuperação dos canaviais, essa função é desvalorizada e precarizada nos canaviais e vista como uma função mais leve e adequada para as mulheres, às quais cabe arrumar a bagunça deixada pelos homens. As próprias bituqueiras aceitam essas distinções do masculino e feminino que predomina nesse espaço de trabalho, de modo que a segregação sexual é reforçada por tais estereótipos. Silva (2011) observou que o vestuário das bituqueiras é composto por um pano no rosto, ficando somente os olhos de fora, a saia é vestida sobre a calça comprida para impedir que o corpo feminino aparente possa despertar o desejo dos homens.

O objetivo desta pesquisa é analisar as estratégias de defesa individuais e coletivas (Dejours) mobilizadas por trabalhadoras do agronegócio para lidar com o estranhamento do trabalho (Antunes) e os mecanismos sociais de habituação do trabalhador (Braverman). A questão de pesquisa: como as bituqueiras enfrentam os processos de habituação e de estranhamento na realização de um trabalho que é rigidamente organizado e precário? A pesquisa foi realizada com nove mulheres que exercem o trabalho de bituqueiras, elas têm a função de recolher os restos da cana que permanecem no solo após o corte e o carregamento da produção. Os dados foram coletados por meio de entrevistas semiestruturadas e o método de análise de conteúdo foi empregado para a análise das entrevistas. As entrevistas abordaram temas relacionados tanto com a tarefa quanto com o sujeito.

Além desta seção de introdução, este artigo apresenta outras cinco seções. A próxima seção trata dos conceitos de habituação do trabalhador e estranhamento do 
trabalho na sociedade capitalista. A seção seguinte aborda as estratégias de defesa do trabalhador frente ao sofrimento no trabalho. A seguir, uma seção com os procedimentos metodológicos e uma seção com a apresentação e análise dos resultados. Uma seção de conclusão encerra o artigo.

\section{ESTRATÉGIAS DE HABITUAÇÃO DO TRABALHADOR E ESTRANHAMENTO DO TRABALHO NO SISTEMA CAPITTALISTA: UMA ABORDAGEM SOCIOLÓGICA}

A empresa capitalista tem como propósito a expansão do capital. Tal fato torna inerente àquela a busca por produtividade crescente, mediante a intensificação de desenvolvimento tecnológico promovido e aplicado a partir do critério de lucratividade, em que se desconsidera amplamente "efeitos sociais" como: redução do número de trabalhadores com carteira assinada; aumento do número de trabalhadores disponíveis para uso na concorrência entre as empresas pelos excedentes; aumento de desemprego; destruição de algumas ocupações e, por vezes, criação de outras que não necessariamente perfazem o número dos demitidos pelas ocupações destruídas, criando um excedente relativo de mão de obra disponível para emprego a taxas inferiores de salário (BRAVERMAN, 1987, p. 178). Nesse processo de intensificação tecnológica, o controle do trabalhador é reduzido, quando não totalmente substituído, por dispositivos automáticos (dominação do trabalho morto sobre o trabalho vivo) que possibilitam o controle pela própria gerência.

A vida de trabalho torna-se caracterizada por uma série de empregos e também pelo desemprego prolongado, pois esses têm seus papéis alternados: ora estão entre a população dos trabalhadores, em outra parte do tempo estão na reserva de trabalho ou estão recorrendo ao seguro desemprego; o fato de viver de emprego ocasional e marginal leva esta população a viver em condições precárias. Todavia, para Braverman (1987, p. 179), a "desventura" do trabalhador não está apenas na frequência com que esse faça parte do exército de reserva. Na medida que se perde a distinção entre trabalho produtivo e improdutivo, o cálculo de produtividade se aplica mesmo para aquele estrato privilegiado da classe trabalhadora, mais próxima do empregador e detentora de certos privilégios. Já para aquele estrato amplo de trabalhadores produtivos (por meio dos quais se criava a mais-valia) perde-se "as características de produtor de uma mercadoria acabada" e passa a reter apenas "aquelas características na massa". Com a divisão do trabalho, é o coletivo que produz, e todo o conjunto de trabalhadores se tornou "trabalhador produtivo", isto é, todos estão sujeitos ao cálculo da produtividade. E, conforme Marx, ser um trabalhador produtivo não é motivo para felicidade, visto que, na sociedade capitalista, o tempo livre "é produzido para uma classe mediante a transformação de todo o tempo de vida das massas em tempo de trabalho" (MARX, 1984, p. 120).

Neste contexto, as "mulheres constituem a reserva ideal de trabalho para as novas ocupações", afirma Braverman (1987, p. 326). As razões para isso estão relacionadas com o tempo de entrada da mulher na era do capital monopolista, o grande número em que essas estão disponíveis para o capital e o crescimento maior (comparado ao masculino) do número de mulheres que participam do emprego devido às necessidades de subsistência criadas pelo capitalismo. As mulheres não apenas "são remuneradas em escala consideravelmente mais baixa que os homens", mas também ocupam posições menos remuneradas, ou são menos remuneradas dentro da mesma ocupação que os homens (BRAVERMAN, 1987, p. 332).

Por fim, tem-se a questão da qualificação ou a tese da 'superiorização'. Para Braverman (1987, p. 359) era necessário enfrentar uma afirmação quase universalmente aceita pelo senso comum e pelo discurso acadêmico: as condições mutáveis do trabalho na indústria, no comércio, nos serviços, em escritórios, exigem que a população trabalhadora seja cada vez mais instruída. Ele avalia que tal tese parece ser considerada tão evidente que dispensa demonstração e esclarecimentos sobre a distinção entre qualificação, instrução e educação. O que se deve avaliar, conforme o autor, é se o conteúdo científico e de educação do trabalho tende para a mediana ou para a polarização, e se o maior tempo de escolaridade média implica equivocadamente aceitar que uma parcela crescente da população trabalhadora ocupa posições que exigem qualificações mais substanciais.

A análise feita por Braverman (1987) sobre as implicações da tese da 'superiorização' nos leva a refletir sobre várias questões. Essas são apresentadas aqui, livremente, em forma de perguntas que nos levam também a pensar no alcance das análises do autor para os dias atuais: (a) quais são os ganhos para a massa de trabalhadores com o declínio do seu controle sobre o processo de trabalho e o crescente comando das gerências? Ou os ganhos oriundos do preconceito que classifica "todos os 'engravatados' acima de todos que usam 'macacão"'? (BRAVERMAN, 1987, p. 368); (b) está ocorrendo uma simples alternância de trabalhadores de alguns grupos ocupacionais menos 
qualificados para outros grupos mais qualificados?; (c) por que as estatísticas de um censo (referência a um censo realizado nas ocupações nos EUA, na década de 30) criado a partir de artifícios dos classificadores podem classificar um operário da linha de montagem, sujeito à rotinização, como detentor de maior qualificação que um pescador de ostras, um jardineiro ou jangadeiro?; (d) o que significa a classificação de "trabalho não qualificado" ou "zero tempo de preparação", pois pode afinal um ajudante de carpinteiro ser útil ao carpinteiro se não for qualificado?; (e) por que práticas nomenclaturas de classificação criam algumas categorias mais elevadas de qualificação e transformam a maioria do trabalho urbano em trabalho "semiqualificado"?; (f) por que naquela classificação da população de trabalhadores agrícolas, todos são classificados na categoria "trabalhadores agrícolas e capatazes" e não analisa a vasta gama dessa população de trabalhadores? Essa população foi a que sofreu a mais completa dizimação (BRAVERMAN, 1987, p. 367).

Assim, Braverman (1987, p. 179) considera que o salto de eficiência e produtividade dos homens, das mulheres e das máquinas em nações capitalistas conduz a uma degradação da população e da vida social, sob o argumento de salvar o sistema. Em busca de aumentos constantes de produtividade, a indústria (incluindo a agroindústria), o comércio e o setor de serviços racionalizam, mecanizam, inovam e revolucionam o processo de trabalho em ritmo acelerado e com o uso dos mais diversos recursos da ciência e da tecnologia. $\mathrm{Na}$ abordagem marxiana, conforme Braverman (1987, p. 329), a acumulação do capital corresponde à acumulação do pauperismo (MARX, 1984, p. 120). Ele também faz referência à Adam Smith, quando conclui que, ao invés de "riqueza das nações", a preocupação da pesquisa econômica e das gerências capitalistas da época é com a "prosperidade", a qual não está relacionada com "a eficácia do trabalho na produção de bens úteis e serviços", mas tão somente relacionada com a "velocidade do fluxo dentro dos circuitos do capital e mercadorias no mercado" (BRAVERMAN, 1987, p. 352). Todavia, o autor avalia que as estratégias de habituação do trabalhador aos novos modos de produção capitalista não eliminam a hostilidade, o sarcasmo e a repulsa dos trabalhadores às formas degradadas de trabalho a que esses são obrigados.

O conceito de estranhamento do trabalho é desenvolvido por Antunes (1995, p. 125), a partir dos estudos de Marx e de Lukács, como "expressão de uma relação social" fundada na desumanização. Essa relação social, baseada "na propriedade privada e no dinheiro", coloca "barreiras sociais que obstaculizam" o desenvolvimento humano. Assim, ao realizar um trabalho estranhado, o trabalhador não se sente "livremente ativo" e não vive conscientemente sua humanidade (ANTUNES, 1995, p. 126).

O trabalho é originariamente uma categoria universal, que permite o desenvolvimento da capacidade teleológica do ser social, capacidade do ser social de previamente imaginar, desejar, tomar consciência e desenvolver conhecimento concreto, "mesmo que não seja perfeito", de um processo de trabalho, com base em "alternativas possibilitadas pela realidade"; ao colocar esse processo "em movimento", a ação teleológica lida com as restrições e limites das "causalidades presentes nessa mesma realidade e que foram postas pelo conjunto dos atos humanos" (ANTUNES, 1995, p. 122; LUKÁCS, 1978, p. 8). Na vida humana, o trabalho não é um epifenômeno, não é buscado apenas para satisfação de necessidades, ao modo de outros animais. Ao contrário, é um "momento fundante de realização do ser social, condição para a sua existência" (ANTUNES, 1995, p. 123; LUKÁCS, 1979, p.8).

No sistema capitalista, a força de trabalho se torna mercadoria cuja finalidade é a produção de mercadorias, ou seja, o trabalho torna-se um meio para satisfazer necessidades fora dele e única forma de subsistência, ao invés de forma humana de desenvolvimento. $\mathrm{O}$ estranhamento do trabalho se efetiva duplamente: (a) em relação ao resultado do processo de trabalho, visto que o produto "aparece estranhado junto ao trabalhador", ou seja, como algo "alheio" (alienação) o trabalhador se torna coisa (coisificação); em relação ao processo de produção, visto que não se trata de trabalho voluntário, mas, compulsório, com o qual o trabalhador não se satisfaz, não deseja ou não se reconhece. $\mathrm{O}$ capitalismo avançado, segundo o autor, estendeu a "problemática do estranhamento na sociabilidade contemporânea" até "a esfera do consumo" (ANTUNES, 1995, p. 129).

Disso decorre um universo de "manipulação de necessidades" e o sentimento de uma liberdade (apenas aparente) de satisfação dessas necessidades. Essa manipulação (ANTUNES, 1995, p. 129-130) é exercida pelo uso de "um arsenal mercadológico" e das mídias de massas, enquanto as necessidades são "reduzidas e homogeneizadas". Essas necessidades emergem da posição de uma pessoa na "divisão do trabalho" e não de seu "desenvolvimento" ou realização humana. Para o trabalhador, o "caráter intolerável do sistema" não está "na impossibilidade de satisfazer suas necessidades elementares", esse está, antes de tudo, "na consciência

Organizações Rurais \& Agroindustriais, Lavras, v. 19, n. 1, p. 31-46, 2017 
da alienação" e no sentido para a vida. Assim, Antunes (1995, p. 132) lembra que há uma "plasticidade no problema do estranhamento", que conecta necessariamente o "desenvolvimento das forças produtivas" com o "desenvolvimento da capacidade humana", mas não necessariamente em um sentido emancipador. Portanto, as consequências de tal estranhamento podem ser o desfiguramento e o aviltamento da personalidade humana.

\section{ESTRATÉGIAS DEFENSIVAS FRENTE AO SOFRIMENTO NO TRABALHO: CONTRIBUIÇÕES DA PSICODINÂMICA}

Nesta pesquisa, adota-se uma distinção entre os termos defesas e resistências, defendida por SeligmannSilva (2011). Ambas têm em comum o fato de apresentarem um caráter individual e um caráter coletivo, porém, a resistência está voltada diretamente para o enfrentamento e a transformação das situações ou condições que dão origem ao sofrimento; e as defesas, realizadas "através de mecanismos psicológicos ou de conduta", estão voltadas "basicamente para evitar ou tornar suportável o sofrimento", são formas de enfrentamento que, em geral, não geram transformações (SELIGMANN-SILVA, 2011, p. 368). Em relação às defesas, elas podem ser conscientes ou inconscientes. Outra distinção é adotada nesta pesquisa, conforme Dejours (2005) e Seligmann-Silva (2011), diz respeito ao termo mecanismos psicológicos individuais de defesa (essas defesas são inconscientes, mas podem ser trazidas à consciência) e aos termos estratégias individuais de defesa e sistemas coletivos/sociais de defesa no trabalho (essas defesas são conscientes, mas se articulam em algum grau com mecanismos psicológicos de defesa, inconscientes, e com as crenças da prática profissional). Neste artigo, o foco são as estratégias individuais e coletivas de defesa.

Os estudos sobre os mecanismos psicológicos de defesa, inicialmente realizados por Anna Freud e publicados em 1936 (FREUD, 2006), antecedem os estudos sobre estratégias defensivas no trabalho, especificamente aqueles realizados, nos anos 1980, por Dejours (2005). Os estudos de Anna Freud têm por base a estrutura psíquica proposta por seu pai Sigmund Freud: ego, Id e superego (FREUD, 1997). Ao longo do tempo, os estudos sobre estratégias defensivas no trabalho adotaram termos que foram propostos e desenvolvidos clinicamente nos estudos sobre mecanismos psicológicos de defesa, no campo da Psicologia e Psicanálise: negação, repressão, racionalização, formação reativa, isolamento, dentre outros. Isto ocorre porque, a despeito da natureza coletiva da construção das estratégias defensivas, os indivíduos viverão o sofrimento ou o prazer no trabalho de maneira singular. E, conforme Dejours (2007), é necessário algum grau de coerência e/ou harmonização entre os mecanismos de defesa psíquicos individuais e o sistema de defesa coletiva.

Se os mecanismos de defesa psicológicos são manifestações do ego para lidar com as incursões/ exigências/ameaças do Id e superego, contra o que as estratégias individuais e os sistemas coletivos de defesa são construídos? No início do século XX, interessada na dinâmica psíquica, Anna Freud (2006, p. 29) afirmou "sempre que ocorre a transformação de um afeto, seja na análise ou fora dela, o ego esteve em ação e temos uma oportunidade para estudar seu funcionamento". Nos anos 1980, interessado na psicodinâmica do trabalho, Dejours (2005) mostrou que o sofrimento operário produz sintomas - a insatisfação e a ansiedade - e o trabalhador desenvolve estratégias defensivas para lidar com esses sintomas: adormecimento e paralisia intelectual, negação, desprezo e pseudoinconsciência do perigo, burlas à organização do trabalho, transmissão e aplicação de "macetes" e "dicas" que resultam de longo tempo de observação, experiência e aprendizado de uma tarefa ou ocupação.

As defesas psicológicas individuais estão presentes em trabalho perigoso, trabalho extenuante e/ ou tediante e trabalhos que geram mal-estar ou angústia (SLIGMANN-SILVA, 2011). Os sistemas coletivos de defesa emergem da falta de autonomia e da insatisfação do trabalhador no trabalho, com a experiência forçada de realizar uma tarefa desinteressante, a qual produz uma imagem de indignidade, um sentimento de vergonha e de desqualificação pelo não reconhecimento dos organizadores do trabalho da capacidade do trabalhador de conhecer e imaginar, a despersonalização e a fadiga. A indignidade também produz um sentimento de inutilidade e, portanto, uma imagem "narcísica pálida, feia, miserável" (DEJOURS, 2005, p. 49). Esse sentimento está associado ao argumento da falta de qualificação, mas também com um entendimento da falta de significação do trabalho realizado não propriamente para o conjunto de atividades realizadas na empresa, mas para o próprio trabalhador, a sua família e seu grupo social, ou para o desenvolvimento da sociedade.

As estratégias defensivas funcionam como "regras de trabalho" (acordo normativo), pressupõem "um consenso ou acordo partilhado" que depende necessariamente de determinadas condições externas. Quanto à eficácia simbólica das estratégias defensivas, 
ela é assegurada pela participação de todos na construção e manutenção de um sistema de defesa - uma "percepção irrealista da realidade" do trabalho, uma "realidade reconstruída" e "validada coletivamente" (DEJOURS; ABDOUCHELI, [1990]2015, p. 129) "por vários sujeitos experimentando cada um por si um sofrimento único", porém "capazes de unir seus esforços para construir uma estratégia defensiva comum".

Dificilmente, os indivíduos podem lidar de forma solitária com as pressões organizacionais. A negação dos riscos, a autorrepressão do medo, a elaboração de fantasias e o uso da música e de amuletos/orações utilizadas para amenizar tédio, o desgaste, o cansaço ou o sono, as brincadeiras para quebrar a tensão ou a raiva, as idealizações contra a exploração e pela autovalorização, essas são defesas conscientes de indivíduos que dão origem a sistemas sociais (coletivos) de defesa específicos de cada profissão, conforme "a sociabilidade e as perspectivas existenciais" do grupo (SELIGMANN-SILVA, 2011, p. 382).

Ambos, estratégias psicológicas de defesa e sistemas socialmente estruturados de defesa são aspectos dinâmicos da vida no trabalho. Portanto, não são duradouros e independentes da situação/condições em que essas ocorrem. Alguns eventos podem romper essas estratégias: acidentes de trabalho, adoecimento e crises mentais agudas, demissão e/ou desemprego (SELIGMANN-SILVA, 2011). O desemprego, porém, pode dar origem a outras estratégias defensivas utilizadas por desempregados para lidar com o sofrimento psíquico do desemprego (OLIVEIRA; MENDES, 2014). No caso dos trabalhadores que migram em busca de trabalho no agronegócio, Costa e Silva (2011) analisaram a presença do sofrimento psíquico e de estratégias defensivas de trabalhadores nordestinos que migram para os canaviais de São Paulo e daqueles que ficam no nordeste do país: familiares.

Esse caráter coletivo de um sistema partilhado pelos profissionais de uma categoria também tem um valor funcional em relação à produtividade e à coesão do grupo. Aquele trabalhador que não consegue suportar a ansiedade, o risco ou o medo, que não consegue incorporar em seu discurso e comportamento as estratégias defensivas da categoria profissional a que pertence, provavelmente será demitido ou se demitirá (DEJOURS, 2005). Desse modo, quando bem-sucedidos, os mecanismos psicológicos de defesa reduzem a ansiedade e os conflitos intrapsíquicos, quando malsucedidos dão origem a neuroses, psicoses, doenças psicossomáticas. Quando bem-sucedidas, as estratégias de defesa reduzem a ansiedade do trabalhador e o tornam apto para o trabalho, quando malsucedidas provocam adoecimento, demissão ou pedido de demissão pelo trabalhador. Um outro aspecto crítico no estudo de um sistema defensivo é que ao mascarar o sofrimento e produzir "certo grau" de estabilidade frente às pressões da organização do trabalho, essas estratégias produzem a alienação: a estratégia se torna, assim, "um objetivo em si mesma" e o sofrimento "não pode mais ser reconhecido como decorrente do trabalho" (DEJOURS; ABDOUCHELI, [1990]2015, p. 130). Quando a defesa das estratégias de defesa passa a ser um fim, tem-se instituída uma "ideologia defensiva" e não mais estratégias coletivas defensivas.

\section{PROCEDIMENTOS METODOLÓGICOS}

Esta pesquisa adota as perspectivas epistemológicas interpretativistas e do estruturalismo radical (BURREL; MORGAN, 2011) ao tratar de (des)realização e sofrimento. A abordagem dos dados é qualitativa (DENZIN; LINCOLN, 2006). O método de investigação é o método dialético, ao buscar o contraste entre dois conceitos com alto grau de abstração, habituação do trabalhador e estranhamento do trabalho, e mostrar que eles não geram automaticamente aquilo que expressam, pois, os trabalhadores, individual ou coletivamente, desenvolvem estratégias de defesa (categorias de análise).

A coleta de dados foi conduzida pela técnica de entrevista individual e semiestruturada (DENZIN, 1977), realizada face a face. Para a seleção dos sujeitos de pesquisa, foi adotada a estratégia de caso típico (PATTON, 1990), ou seja, o público pesquisado possibilita a análise do conceito/problema de pesquisa. Para o estudo de estratégias de defesa em um trabalho rigidamente organizado, foram entrevistadas mulheres que exercem a função de bituqueiras em empresas do setor sucroenergético, localizadas no estado de Minas Gerais.

$\mathrm{O}$ guia de entrevistas foi estruturado em seis tópicos: a história de vida da entrevistada; a descrição do dia a dia na empresa; a avaliação dos aspectos positivos do seu trabalho; a avaliação das dificuldades do seu trabalho; as expectativas concretizadas e não concretizadas na e devido à ocupação; os planos para o futuro. As entrevistas foram gravadas e transcritas (SILVERMAN, 2009). Na análise das entrevistas, buscou-se identificar as estratégias de defesa mobilizadas pelas entrevistadas, considerando o sofrimento e o contexto desse sofrimento (a organização, as relações e as condições do trabalho). As entrevistas (Quadro 1) foram realizadas em local escolhido pelas entrevistadas, em 2013, nas cidades de Ituiutaba/MG e Canápolis/MG (cidades produtoras de cana-de-açúcar da região do Triângulo Mineiro). 


\begin{tabular}{|c|c|}
\hline Nome & Breve descrição do perfil \\
\hline Dora & $\begin{array}{l}\text { Migrante, solteira, } 03 \text { filhos, analfabeta, } 56 \\
\text { anos de idade. }\end{array}$ \\
\hline Ester & $\begin{array}{l}\text { Migrante, união estável, } 02 \text { filhas, ensino médio } \\
\text { incompleto, } 48 \text { anos de idade. }\end{array}$ \\
\hline Inês & $\begin{array}{l}\text { Migrante, união estável, } 03 \text { filhos, ensino } \\
\text { fundamental incompleto, } 52 \text { anos de idade. }\end{array}$ \\
\hline Aline & $\begin{array}{l}\text { Migrante, casada, } 03 \text { filhos, ensino fundamental } \\
\text { incompleto, } 34 \text { anos de idade. }\end{array}$ \\
\hline Helena & $\begin{array}{l}\text { Migrante, casada, } 02 \text { filhos, ensino fundamental } \\
\text { incompleto, } 24 \text { anos de idade. }\end{array}$ \\
\hline Carla & $\begin{array}{l}\text { Não-migrante, separada, } 01 \text { filho, ensino } \\
\text { fundamental incompleto, } 34 \text { anos de idade. }\end{array}$ \\
\hline Beatriz & $\begin{array}{l}\text { Migrante, casada, } 03 \text { filhos, ensino fundamental } \\
\text { incompleto, } 30 \text { anos. }\end{array}$ \\
\hline Fátima & $\begin{array}{l}\text { Não-Migrante, união estável, } 02 \text { filhos, } \\
\text { ensino fundamental incompleto, } 39 \text { anos } \\
\text { de idade. }\end{array}$ \\
\hline Giane & $\begin{array}{l}\text { Migrante, solteira, } 01 \text { filha, ensino fundamental } \\
\text { incompleto, } 35 \text { anos de idade. }\end{array}$ \\
\hline
\end{tabular}

Fonte: Elaborado pelos autores

\section{APRESENTAÇÃO E ANÁLISE DOS RESULTADOS}

O trabalho de bituqueiras na moderna empresa do setor sucroalcooleiro tem semelhanças visuais com $o$ trabalho de mulheres que trabalhavam como respigadeiras, no século XIX, recolhendo as espigas que sobravam após a ceifa (SILVA, 2011; 2013). A atividade de respigadura, daquela época, foi retratada, conforme Figura 1. A ideia de respigadores modernos é apresentada no documentário "Os respigadores e a respigadora" (VARDA, 2000), dirigido por Agnès Varda.

A partir da revisão da literatura, foram identificadas as estratégias de habituação da trabalhadora nos canaviais e as condições de estranhamento desse trabalho de bituqueira, e com base nas entrevistas realizadas foram analisadas as estratégias de defesa individuais e o sistema social de defesa criado por essas trabalhadoras, conforme Figura 2.

As entrevistadas analisam a imigração, visto que a maioria dos trabalhadores (homens e mulheres) é de outros estados, justificando que mulheres e homens da cidade não têm capacidade (disposição) para realizar o trabalho nos

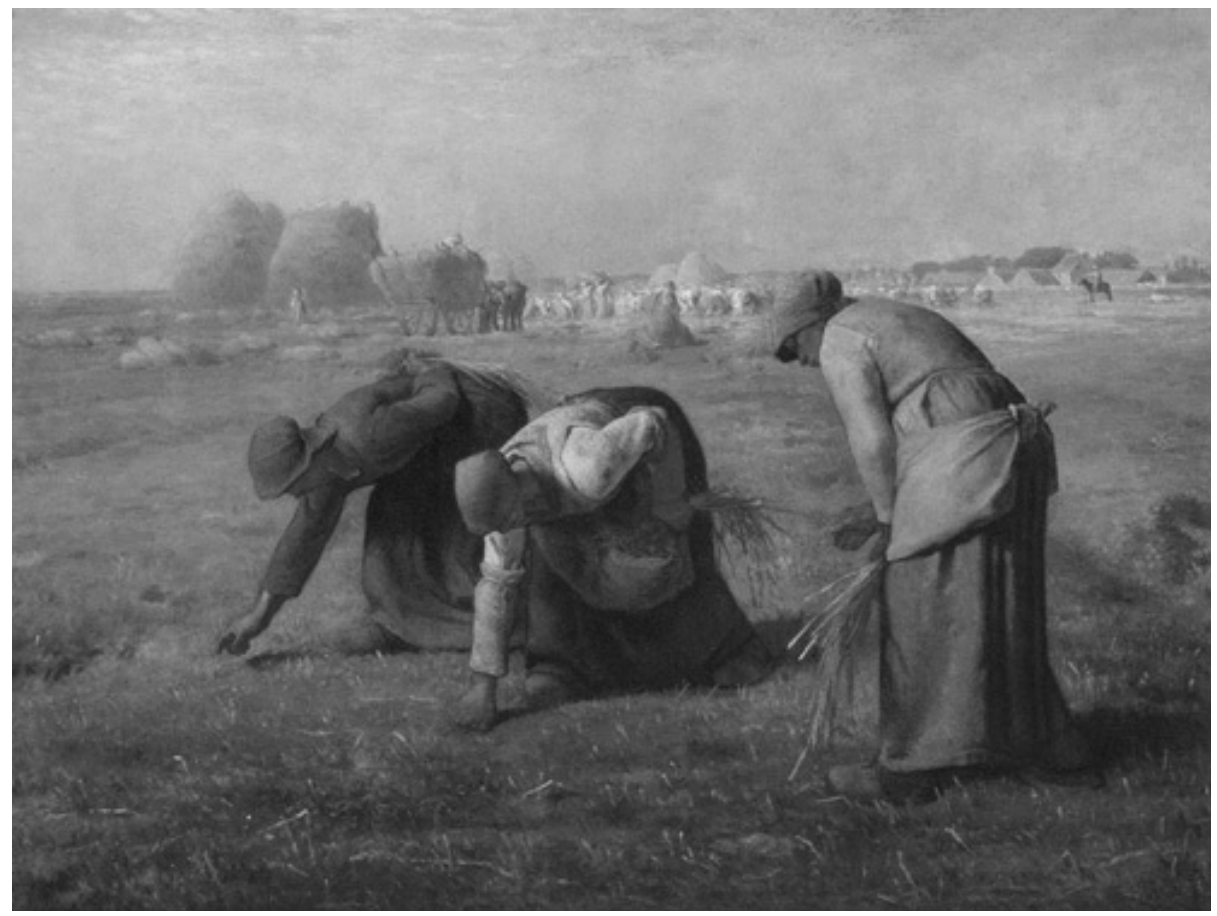

FIGURA 1 - The Gleaners, 1857, por Jean-François Millet (1814-1875)

Fonte: Musée d'Orsay (2013) 


\section{Estratégias de habituação da trabalhadora nos canaviais}

(a) tecnologia e forças socioeconômicas que destroem as demais formas de organização do trabalho: rígido controle do trabalho nos canaviais, intensificação do uso de máquinas no corte de cana;

(b) politicas de trabalho que asseguram o aumento da produtividade: baixos salários e intensificação da produtividade em uma estrutura agroindustrial composta por poucas grandes empresas;

(c) uso de elementos manipulativos: crise econômica, políticas de emprego e desemprego;

(d) a destruição de outros modos de vida: redução de oportunidades para trabalho com baixa qualificação e pouco investimento no pequeno produtor.

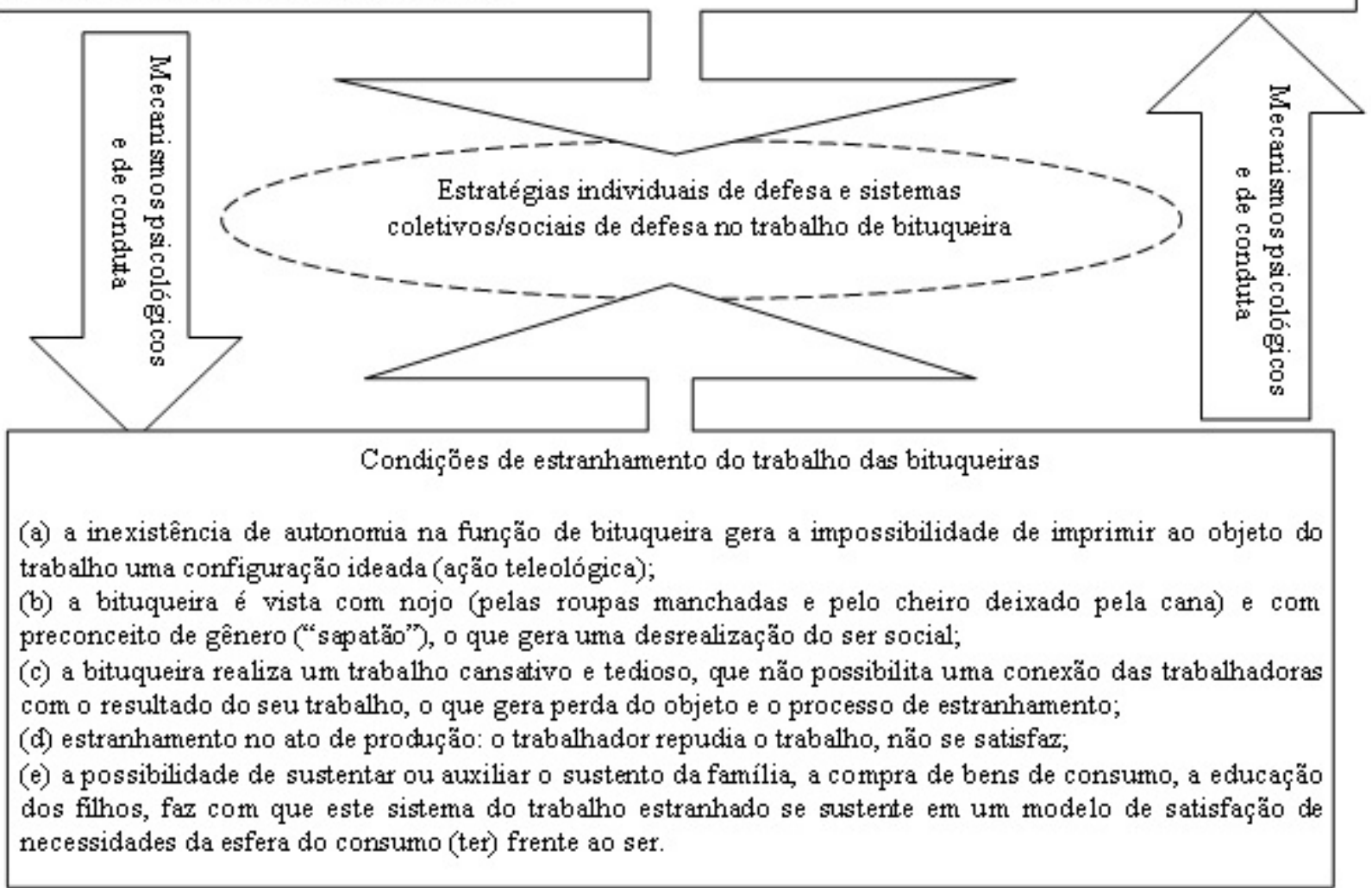

FIGURA 2 - Estratégias de defesa: interdependências com as estratégias de habituação e o estranhamento do trabalho Fonte: Elaborado pelos autores

canaviais. Em relação à participação em sindicatos, algumas confirmam serem filiadas, mas não participam das reuniões: "A gente que é mulher, a gente não tem tempo pra ir pra essas coisas não, sabe?" (Dora). Elas explicam que têm muito trabalho em casa e, por isso, ao invés de ir às reuniões dos sindicatos, elas buscam informações sobre a reuniões com os homens ou um representante da turma que foi à reunião.

Os homens são maioria entre os fiscais, cortadores de cana e operadores de máquina. Mas, no dia a dia, existem muitas outras atividades que são distribuídas pelo fiscal. E na distribuição, para Carla e Beatriz, as mulheres quase sempre ficam com atividades mais pesadas que os homens, "por que os homens são os homens!". Também quando questionada sobre o comportamento de homens e mulheres frente a situações em que ocorre o atraso do pagamento e da cesta básica, Carla avalia que "os homens fazem a greve. [...] as mulheres não têm coragem". Ela justifica que talvez esse fato esteja relacionado com a desproporção entre o número de mulheres e homens naquele espaço, e cita um exemplo: apenas dois ônibus com mulheres (cerca de 90) e doze ônibus com homens (cerca de 540).

Organizações Rurais \& Agroindustriais, Lavras, v. 19, n. 1, p. 31-46, 2017 
QUADRO 2 - Medo da demissão: estratégias individuais e sistema coletivo de defesa

Tema 1: medo da demissão devido às poucas opções de trabalho locais e à necessidade de sobrevivência da mulher com baixa qualificação.

Estratégias individuais de defesa: submissão e evitação do conflito, valorização (negação) dos baixos salários da bituqueira, fantasia a respeito do salário da bituqueira e do não engajamento em greves.

Base para o sistema coletivo de defesa: trabalhadoras bituqueiras se veem como sobreviventes, para além da falta de oportunidades, o que facilita e potencializa o controle por parte da empresa.

Narrativas

[...] "as mulheres daqui não têm coragem de enfrentar o que nós enfrentamos na bituca, as mineiras não têm" (Dora)

[...] "esses [homens] daqui não dão conta de cortar cana igual eles não". (Carla)

[...] dentro da usina... não, eu prefiro trabalhar ... eu prefiro trabalhar lá no campo mesmo. Dentro da usina não, porque o salário dentro da usina é pouco, é só um salário [mínimo]. [Eu prefiro trabalhar] no campo mesmo!. (Carla)

Se você chega cedo, se sabe o que tem que fazer, tem seu fiscal que fala: "Olha! É para ir fazendo, isso... já manda. (Carla)

Aí se você for cobrar algo deles [empresa], “Ai, mas eu não vou trabalhar sem receber!”. Ah, mas se você não for trabalhar você toma falta! [..] Você vai levar o que para comer? Vento? Por que é que a gente trabalha lá? A gente depende do serviço. (Aline) A gente não reclama porque tem medo de ser mandada embora. Porque tem medo de ficar sem o serviço, aí ninguém reclama. [...] Eu preciso do meu dinheiro! [...] Todo mundo calado. (Carla)

E assim a firma, hoje em dia, dá valor enquanto você está trabalhando e enquanto você está indo. Na hora que você começa a faltar, começa a levar atestado [médico], acabou! Você não tem mais valor, não! Eles não estão nem aí. (Beatriz)

Nós mulheres... nós temos medo [referência à greve], porque a opção de serviço que tem aqui [cidade] é a [empresa], é a bituca... para mulher é a bituca e quem não consegue e não está acostumado a trabalhar, não consegue! [...] passa uma necessidade e não tem outra opção de serviço.(Fátima)

Eu prefiro essa função do que outra função aí. Eu não, eu não dou conta de ficar lavando banheiro de ninguém. Eu prefiro é... trabalhar na roça... [...] Eu não tenho estudo. (Inês)

Quero dez mil vezes tá na bituca, mas eu não quero tá na cozinha dos brancos. [...] (Ester)

Bituqueira nunca fez greve, geralmente os cortadores fazem greve! (Helena)

Porque eles cobram muito do fiscal, e o fiscal cobra da gente, aí vem o encarregado e fala uma coisa, vem outro e fala outra, você não sabe nem com quem... quem tá mandando, quem manda mais?! Então, isso que provoca mais assim aquele estresse mesmo, aquela vontade de sair e abandonar tudo?! Mas aí a gente pensa assim: "A gente precisa, a gente está lá porque... a gente precisa trabalhar para comer! E, sobreviver !" (Aline)

Fonte: Elaborado pelos autores

No trabalho com as bitucas, é preciso cumprir a meta. O salário de um mês de trabalho de uma bituqueira pode chegar a $\mathrm{R} \$ 1.200,00$, o pagamento é fixo em diárias de $\mathrm{R} \$ 29,90$. Quando questionadas, se acham justo o salário que recebem, elas dizem que não é justo, mas é o salário que elas encontram em outras ocupações; dentre essas, o trabalho de doméstica. Esse último não gera o interesse das entrevistadas. Elas explicam que sofrem humilhações e são exploradas pelas patroas no serviço doméstico. Por isso, elas preferem o trabalho de bituqueiras, na roça, ao trabalho dentro da usina. Isso porque o valor pago para o trabalho na usina é menor (um salário) e o trabalho inicia às 7 horas e se estende até 17 horas ou mais. As entrevistadas explicam que o fato de não terem estudado lhes deixa poucas oportunidades de emprego na cidade e região, o que afinal limita suas escolhas na vida - elas se veem como sobreviventes, para além da falta de oportunidades (Quadro 2).
Em relação às condições de trabalho, as entrevistadas relataram que não há treinamento para o exercício da função. Geralmente, no campo, os fiscais mostram onde o trabalho deve ser realizado e informam que elas devem acompanhar e realizar o trabalho conforme outras trabalhadoras, com mais tempo de trabalho na função. Os equipamentos de trabalho são boné, caneleira, botina, luva e óculos, "mangote" (camisa de mangas compridas), uma garrafa para água e marmita. A calça comprida é a própria trabalhadora que providencia, a exigência da calça é para evitar que o corpo fique exposto na medida que elas realizam os movimentos constantes de se abaixarem e levantarem. As trabalhadoras explicam que, se elas perdem um desses equipamentos, a empresa cobra pelo fornecimento de um segundo. Quando termina o período de trabalho, elas têm que devolver os equipamentos. A maioria delas manifestou grande insatisfação com atrasos 
frequentes nos pagamentos. A empresa não oferece refeição, então elas têm que levar de casa, a comida é transportada por elas em marmita. Muitas relataram que comem a comida fria, quando a comida estraga, não há o que comer. A empresa oferece uma garrafa de água que elas têm que carregar. Em alguns casos, existe uma geladeira no ônibus que faz o transporte das trabalhadoras. As trabalhadoras que moram distante do trajeto do ônibus que faz o transporte precisam utilizar o transporte urbano coletivo até o local ou ponto mais próximo para o transporte oferecido pela empresa. Há banheiros improvisados, que as mulheres se sentem constrangidas de frequentar.

$\mathrm{O}$ trabalho no campo começa às sete horas da manhã e vai até onze horas, com intervalo de uma hora para almoço, e o retorno a partir de doze horas até às dezesseis horas. Quando a meta é alcançada mais cedo, as trabalhadoras informam que podem descansar até o horário de ir embora (7:00-15:00). O trabalho na função de bituqueira ocorre durante cinco dias da semana, em feriados (pagamento dobrado) e domingos (com um dia de folga). No campo, o fiscal recebe um valor pela produtividade do grupo. Mas, além do fiscal, existe um grupo de avaliadores que visita o campo (fiscaliza o trabalho do fiscal e das bituqueiras). As trabalhadoras relatam o uso de uma máquina de cartão de ponto para registrar horário de entrada e saída. Quem esquece o cartão, tem que voltar para casa e perde o dia. As entrevistadas relatam situações de risco e de sofrimento, elas sentem-se exploradas pela chefia direta, discordam das condições indignas de trabalho que causam fadiga e cansaço extremo. Para lidar com os riscos à integridade física e mental, o cansaço e o tédio, elas adotam sistemas sociais de defesa ao ouvir música e compartilhar vídeos, recorrer ao álcool e argumentar que os primeiros dias são os mais difíceis, depois se acostuma - o sentimento de impotência cede espaço para a ideia que as entrevistadas são mulheres vencedoras, que superam quaisquer dificuldades. Até porque as ocupações anteriores ao trabalho de bituqueira incluíram serviço de doméstica, trabalho em plantações de feijão, algodão, arroz, milho (Quadro 3).

A contratação de mulheres, preferencialmente aos homens, para exercer a função de bituqueiras é algo conhecido no universo do trabalho rural. Dora explica que elas são "safristas", ou seja, são contratadas no início da colheita e demitidas ao término, num período que pode se estender por cinco meses. Trata-se de trabalho temporário, cujo processo se repete a cada safra, incluindo as filas no sindicato para o processo de seleção e a publicação da lista com os nomes daqueles que foram contratados. As entrevistadas relatam que as empresas, especialmente no Estado de Minas Gerais, contratam preferencialmente mulheres para a função de bituqueira. Elas relatam que a faixa etária predominante de suas colegas de trabalho é de 30 a 42 anos. Carla avalia que essas mulheres "são mais experientes, estão acostumadas com serviço", enquanto as mais jovens não querem trabalhar. Elas informam que o trabalho de bituqueira, no campo, é realizado em duplas. Neste aspecto, elas isolam o sentimento de raiva diante dos preconceitos e descrevem a sua conduta de mulheres fortes! "Faço tudo que um homem faz!"(Carla) (Quadro 4).

A maioria dos trabalhadores tem celular, sempre que conseguem burlar o trabalho do fiscal, elas usam para fazer ligação e ouvir música, ver vídeo: "conversa... escuta música...e celular tem muito desse negócio de música, de vídeo... e aí uma vai mostrar pra outra, que mostra para outra... e vai passando" (Carla). Na avaliação da entrevistada, embora a empresa tenha proibido o uso do telefone celular, restringindo o uso ao horário de almoço, na prática isso não acontece.

As faltas sem atestado são descontadas, um dia de falta gera a perda de dois (inclui o domingo). As trabalhadoras também explicam que o sol é uma das piores coisas do trabalho, além do pó da cana, especialmente quando estão resfriadas. Elas informam que, além do salário, recebem o vale-refeição, e uma cesta básica; porém, se tiver faltas no mês, perde a cesta. Apesar do trabalho extenuante durante todo o dia, elas ainda têm que desempenhar as tarefas de casa, caracterizando uma dupla jornada de trabalho. Quando questionadas se o que recebem pelo trabalho é justo, as entrevistadas Dora e Inês respondem que sim, mas acrescentam: "Às vezes a gente chora, mas porque você já viu um pobre não chorar?" (Dora), e "A gente faz conta demais. Faz conta e fica pressionada pelas dívidas..." (Inês). Dora relatou problemas com o alcoolismo e violência do primeiro marido. As entrevistadas se veem como mulheres livres, ao menos do ponto de vista financeiro, mesmo que com alto custo para sua saúde física e mental, elas obtêm uma relativa autonomia (Quadro 5).

Quanto ao modo que elas se sentem realizando esse trabalho e sentem que são vistas pela sociedade, as entrevistadas ressaltam que o trabalho na bituca ajudou a mudar a vida delas "ter coisas" (Carla). Para Carla, o trabalho lhe possibilitou ter uma vida melhor, comprou um terreno e construiu uma casa, já não mora mais de aluguel. Inês avalia que, "hoje a mulher é mais independente", e, para ela, a coisa mais ruim para uma mulher casada é "pedir dinheiro para o marido" e "ele perguntar: para que você quer esse dinheiro?". 
QUADRO 3 - Ansiedade frente aos riscos: estratégias individuais e sistema coletivo de defesa

Tema 2: ansiedade frente aos riscos gerados por uma atividade laboral que causa sofrimento físico e mental.

Estratégias individuais de defesa: autorrepressão da raiva e do medo de acidentes, das dificuldades relacionadas ao cansaço provocado pela carga extenuante de trabalho, às condições indignas, aos abusos da chefia direta, negação do sofrimento sistemático com a ideia que os primeiros dias são os mais difíceis.

Base para o sistema coletivo de defesa: o sentimento de impotência cede espaço para a ideia que as entrevistadas são mulheres vencedoras, que superam qualquer dificuldade.

Narrativas

Acho muito pouco... [o salário] pelo sofrimento que você passa sabe, o risco que você corre [...] já aconteceu uma vez que a gente veio para [cidade], e o pneu traseiro do ônibus estourou ... se fosse o dianteiro nós teríamos morrido, ainda bem que era o da frente. Isso era... sete horas da noite, nós chegamos em casa era sete horas da manhã, no outro dia [...] Já aconteceu da gente sair daqui de madrugada e o motorista dormir [ao volante]... (Giane)

Por exemplo, um fiscal, às vezes, tem uma turminha que ele vai com a cara daquela turminha e já com a outra, não. Se vai fazer um serviço mais maneiro, ele joga para aquela turminha que ele vai com a cara, e, às vezes, aquela turminha "puxa-saco" de fiscal, leva merendinha... leva quitanda para ele. Assim, você vai vendo as coisas erradas... assim a gente acha ruim, entendeu? [...] Ainda ficava tirando sarro das outras que tava lá no mais pesado. (Beatriz)

Aquela coisa mais esquisita. No primeiro ano que eu entrei [...] eu vomitava verdinho, eu ficava tontinha, era eu em pé e a roça andando junto comigo e eu tontinha [...] não tinha costume. [...] E, aí eles me trouxeram no hospital. [...] no outro dia eu já não fui, fui no terceiro dia, aí eu comecei a aguentar a trabalhar, você acostuma com aquilo ali. Porque tem que acostumar, se você desistir... (Beatriz)

A água, você leva na hora que você sai de casa... Quando tem na roça... onde a gente trabalha...[...] eles levam água, só que a água é quente [...] a água é quente! A maioria das vezes, as pessoas ficam doentes. (Giane)

Na bituca... você tem que encher as mãos e os braços, sair abraçado com aquilo, atravessar... atravessar [...]com aquelas cana porque você não pode deixar... [...] o que cansa na bituca é andar, você tem que andar muito [...] então... é cansativo. (Giane)

Porque a maioria fala "nossa, acordar de madrugada, comer comida fria, você se arrisca a ser mordido por uma cobra..." É arriscado, acontece isso! [...] Uma vez aconteceu de eu colocar a mão em cima da cobra, pegou na luva ... ela ficou pendurada na luva... e eu gritando com medo dela se soltar e vir no meu rosto, sabe? (Giane)

Se você tiver assim ... parado, conversando... parar muito para beber água. Aí ele [o fiscal] chega e fala: você está parando demais, está conversando demais! (Carla)

Dá muita dor nas costas, eu acho assim, isso aí é cansativo [abaixar, e levantar, vezes seguidas]. Eu acho que o pior é você comer a comida gelada [...] Às vezes a comida azeda, aí você tem que ficar sem... sem comer porque não tem como você comprar as coisas, sabe? [...] Ou acaba a água, sabe? Aí é bem complicado. (Giane)

É o sol, é o sol, é o dia todo, o dia todo tomando um sol desse... É difícil. É muita dor no corpo, na coluna, dor nas pernas... A sua saúde não é a mesma depois que você entra na coisa, e começa a aparecer ... dores nas pernas, veias, varizes... (Helena)

É, geralmente passa mais é batom, às vezes passam um creme e sempre tem o protetor solar por cima, por que queima o rosto. [...] porque a poeira vem nos lábios da gente, então resseca muito os lábios da gente, tens umas que dá até no sangue, na carne viva. (Fátima)

Conversa... escuta música...é celular tem muito desse negócio de música, de vídeo... e aí uma mostra para outra, que mostra para outra... e vai passando" (Carla).

E chega a ter assim, que a pessoa fica deprimida, que às vezes..., às vezes até usa, tem que beber para segurar um pouco a onda da vida que está difícil. (Beatriz)

Fonte: Elaborado pelos autores

O fato de o trabalho ser cansativo e essas trabalhadoras terem uma longa jornada de trabalho em casa, faz com que elas desistam de iniciar ou dar prosseguimento nos estudos, conforme relatos de Aline e Beatriz. As trabalhadoras explicam que o trabalho é muito difícil, tem que ser muito forte para conseguir realizar. Elas reclamam que o desempenho da função de bituqueira gera dor nos braços, desgaste nos ossos, no joelho, nas costas, nos braços, muitas veias estouram. Os problemas no trabalho junto com os problemas em casa afetam muito essas mulheres e, algumas, se sentem deprimidas, "é desgaste demais né, de certo físico e mental. (Aline). Mas, todas as dificuldades são minimizadas para que os filhos possam ter uma vida diferente - aquela que trabalha para os filhos terem uma vida melhor. Apenas uma delas falou que o filho trabalhou por um período com bituca. 
QUADRO 4 - Angústia e raiva frente às desigualdades de gênero: estratégias individuais e sistema coletivo de defesa Tema 3: angústia e raiva ao lidar com desigualdades nas questões de gênero.

Estratégias individuais de defesa: o isolamento ou separação entre os sentimentos de angústia e raiva gerados por desigualdades de gênero: mulher que trabalha na bituca ou é "sapatão» ou «trai o marido».

Base para o sistema coletivo de defesa: as entrevistadas isolam o sentimento de raiva diante dos preconceitos dirigidos para as bituqueiras e descrevem a sua conduta de mulheres fortes! "Faço tudo que um homem faz!'(Carla).

\section{Narrativas}

Os homens reclamam demais. Eles não querem bitucar. Eles não querem fazer o serviço direito, do jeito que nós fazemos. Porque quando tem muita bituca atrasada, que põem dois homem para ir ajudar, eles ficam reclamando. Eles não fazem o que a gente faz. (Carla) Os homens... os homens lá não aguentam nosso serviço, não aguentam [...] para eles [chefias] é [um trabalho] mais para as mulheres, porque mulher faz o serviço render. O homem não, ele faz corpo mole, ainda mais quando colocam eles para bitucar. (Helena) Eles [colegas de trabalho homens e as chefias] acham que é... que é "sapatão", porque tá trabalhando lá, porque é motorista de caminhão, porque é uma tratorista é "sapatão». É bruto... é bruto... Eu acho que eles acham que a gente é homem igual eles sabe... (Giane)

Eu acho que a mulher tem mais garra! E tem mais força para esse serviço de bituca. Eles [os homens] preferem o cabo da inchada. [...] É o agacha e levanta o tempo todo, não tem uma sobra, não tem nada. Igual agora, que está fora de safra, a gente está roçando o mato que são aquelas grandes moitas de capim. (Helena)

Porque é um serviço [bituqueira] mais sofrido?! Por que mulher aguenta tudo. Homens quando são colocados para bituca, eles catavam duas canas aqui e duas canas ali, e já é demais. E nós? Tá lá ralando... E aí eles batem o pé e falam que não vai, e não há chefe que faz eles irem. (Helena)

Que para enfrentar a bituca tem que ser mulher mesmo, homem não quer. (Fátima)

Para empresa tem [diferença]. Porque a mulher, ela é mais...[...] capricha mais do que o homem. É igual, uma vez que teve uma reunião na [empresa], e eles falaram para nós o seguinte: que se todas as mulheres cortassem cana, eles não precisavam de fiscal... [...] a mulher ..., ela já é mais caprichosa no serviço. (Giane)

Porque o homem, ele é mais... esquentado! Ele é mais... agitado do que a mulher. A mulher não, a mulher tem mais paciência, por isso que eu acho que o serviço da bituca foi feito é para mulher mesmo, porque ela tem maior paciência, o homem não. (Giane) Tem hora que eu tenho vontade de nascer homem e parecer homem. É, ganha mais! O homem fica montado em cima de uma carregadeira e ganha $\mathrm{R} \$ 1.500,00$ ou mil e pouco por mês. A gente trabalha o dia inteiro andando em pé e ganha menos. Tudo para homem é mais fácil! (Inês)

Tem umas que falam que a mulher que trabalha na bituca não presta! Que sabe que lá trabalha muito homem e fala que a mulher que trabalha lá trai o marido. [...](Carla)

Não, a gente acha ruim, porque o povo fala ... que a mulher que vai pra roça ... parece que ela ganha o dinheirinho e fica mais independente, aí o povo ficava falando: "Vai entrar na bituca? A mulher vai ficar sem vergonha, a mulher vai virar a cabeça... [mulher] que trabalha na roça não presta... porque [o povo] ainda fala até hoje. (Aline)

Fonte: Elaborado pelos autores

QUADRO 5 - Valorização do consumo: estratégias individuais e sistema coletivo de defesa Tema 4: valorização do prazer de adquirir produtos vis-à-vis o impossível prazer de um trabalho libertador.

Estratégias individuais de defesa: deslocamento do espaço do trabalho para o espaço do consumo, da falta de autonomia no trabalho, para uma autonomia "relativa" de consumo: celular, geladeira, televisão. A aquisição de bens inclui também terreno e a construção de uma casa própria.

Base para o sistema coletivo de defesa: as entrevistadas se veem como mulheres livres, ao menos do ponto de vista financeiro; elas obtêm uma relativa autonomia, mesmo que com alto custo para sua saúde física e mental.

\section{Narrativas}

Ah! Trabalhar é bom demais! Você está com seu dinheiro ali, você não tem que estar pedindo nada para ninguém: “Ah, compra isso para mim!?”, "Ah, me dê isso!”. Não, você está com seu dinheiro ali, aí você vai lá, você compra. (Aline)

É porque a mulher fica sempre submissa ao marido [...] dependendo do dinheiro do marido, então depois que ela começa a trabalhar ela fica mais independente, ela sabe o que ela quer, ela vai trabalhar, ela ganha o dinheirinho dela, ela sabe o que quer comprar... então não depende mais dele [esposo]... fica mais livre pra fazer o que quer, o que bem entender com o dinheiro dela mesmo [...] acaba tendo coragem (Aline)

Eu vou te falar, eu tenho que sustentar a casa. Porque eu sou o homem e a mulher daqui de casa, sabe. [...] Eu tenho que contar comigo mesma ...(Giane)

Fonte: Elaborado pelos autores

Organizações Rurais \& Agroindustriais, Lavras, v. 19, n. 1, p. 31-46, 2017 
Quando lhe é solicitado avaliar a presença da mulher no trabalho na roça, elas lembram que, no passado, suas mães e avós eram muito dependentes dos maridos. Para Giane, "a maioria dos homens não deixava as mulheres trabalharem ... hoje não, hoje é tudo igual, tem que trabalhar para ajudar o seu companheiro, o companheiro tem que trabalhar para me ajudar...". Elas observam tais transformações na sociedade e mostram que estão buscando essa autonomia também. Elas relatam que tem mulher que atua como fiscal, operando máquinas, trator..."Porque as mulheres de hoje são mais evoluídas, elas têm mais liberdade, elas são mais livres, elas podem ir aonde elas querem ir, não têm aquela opressão do marido ou outro" (Beatriz). As mulheres avaliam que o fato de não terem estudado mais, as deixa vulneráveis no mercado de trabalho em cidades do interior, e recusam o trabalho de doméstica.
Também não desejam que os seus filhos realizem o trabalho de bituqueira(o), querem para eles um futuro melhor. Pelo menos seis delas atribuem suas conquistas ao trabalho de bituqueiras - aquela que exerce um trabalho digno (Quadro 6).

As entrevistadas relatam que muitas colegas se sentem constrangidas e preferem omitir que exercem a função de bituqueiras, quando elas se encontram em determinados espaços sociais públicos ou privados: colégio, escola, na rua, supermercado. Para Aline, essas mulheres têm preconceito e vergonha do seu trabalho - "Muitas têm preconceito do próprio serviço, porque está trabalhando em roça". Aline não consegue entender que essa conduta é um reflexo, até certo ponto compreensível, frente ao tratamento que a empresa e a sociedade reservam ao trabalho nos canaviais e ao trabalho de bituqueira.

QUADRO 6 - A busca de sentido para sua existência: estratégias individuais e sistema coletivo de defesa

Tema 5: busca de sentido para a sua existência vis-à-vis a crueldade da estigmatização e o"nojo social”, a relação com a família, os amigos e a sociedade.

Estratégias individuais de defesa: sublimação com a canalização de interesses no futuro dos filhos, especialmente na educação, visto que a própria trabalhadora não teve oportunidade de estudar e tem que realizar um trabalho estigmatizado, que elas não desejam para os seus filhos; todavia idealizam que a vida desses será melhor que a sua própria historicamente marcada pelo sofrimento.

Base para o sistema coletivo de defesa: as entrevistadas se veem como mulheres que realizam um trabalho estigmatizado, mas para aliviar este mal-estar de serem vistas com crueldade e "nojo social", elas se veem como aquelas que realizam um trabalho digno, o que resulta de um desejo íntimo e profundo de reconhecimento e autovalorização.

Narrativas

A gente faz, você faz muitas amizades [no trabalho], de muitos e muitos anos, mas tem muita coisa ruim! (Aline)

Porque a gente convive com muitas pessoas e constrói muitas amizades com pessoas diferentes. Então é muito gostoso trabalhar com pessoas diferentes na bituca. (Fátima)

Então eu acho assim, que eu tenho muita experiência de... de sofrer muito! Eu falo que é sofrer. (Giane)

Ah, não! Eu não queria esse serviço para ela [referência à filha]... É, eu então não queria que ela trabalhasse nesse serviço. [...] O que eu posso, eu faço para eles estudarem, que é para eu não ver eles nesse serviço. [...] Eu faço de tudo pra eles estudarem... basta eu que já não estudei. (Carla)

Mas foi em 2008, eu consegui comprar a minha geladeira. Então eu fui comprando meus móveis devagar, aumentei a minha casa e depois eu murei[...] (Inês)

Muitas mulheres têm vergonha de falar. [...]Têm muitas que estudam e têm vergonha de falar ... que trabalha na roça. (Aline)

As pessoas olham você com... cara de nojo. Eu acho que é porque a gente chega suja, sabe? As pessoas ficam com medo de pegar alguma doença, porque ela estava suja sabe... acontece isso muito.[...] uma mulher falou "nossa, mas essa mulher está fedendo... [situação vivida por uma colega] (Gina)

Você não pode trabalhar correndo, tem que fazer o serviço bem certo e bem feito! Então é um serviço que eu gosto, eu ganho até bem... E eu gosto do meu trabalho. (Dora)

Meu estudo é pouco para trabalhar numa loja... e eu não quero trabalhar de doméstica... porque paga pouco e exige demais! (Inês)

Fonte: Elaborado pelos autores 


\section{CONCLUSÕES E IMPLICAÇÕES DOS RESULTADOS}

A contratação preferencialmente de mulheres para a função de bituqueira e as possibilidades de (des) realização dessas mulheres ao exercer um trabalho precário e rigidamente controlado foi o ponto de partida dessa pesquisa. Uma das dimensões de análise da pesquisa foram as estratégias de habituação do trabalhador ao trabalho conduzidas pelo sistema capitalista. Conforme observamos, as bituqueiras têm origem humilde e sua história de vida é marcada pela pobreza, nasceram em região geograficamente isolada dos grandes centros, não estudaram o suficiente para conseguir empregos em uma loja, conforme elas afirmam. A vida no interior ficou inviável para elas, que buscaram uma cidade mais próxima dos centros urbanos. Este fato coloca essas mulheres em condições vulneráveis no mundo do trabalho, visto que a promoção de condições e forças socioeconômicas destruíram as demais formas de organização não racional do trabalho. Elas se submetem às condições de um trabalho que degrada, porque leva ao adoecimento, ao desgaste físico e mental. Para elas, porém, parece ser a única opção, ou lhes restaria uma ocupação que também gera enorme desgaste e outros tipos de humilhações: trabalhar de doméstica. A submissão e as fortes defesas individuais construídas as impedem de se engajarem em greves.

A produção ininterrupta na roça é assegurada por um fiscal para cada grupo de 45 mulheres e também por analistas de desempenho que vão ao campo para assegurar que todos estão cumprindo as metas. As bituqueiras recebem um valor fixo, de $\mathrm{R} \$ 29,00$ a diária, mas os cortadores de cana recebem por produtividade. Elas avaliam que o trabalho delas é menos penoso que o deles, porque eles têm que entrar na plantação de cana e aquele pó arde na pele, além dos bichos que ali se escondem. As políticas de crédito levam muitas delas a se endividar. Mas, entendem que a autonomia de ter o próprio dinheiro e não depender do marido as coloca no mundo contemporâneo em que as mulheres são mais livres! Pensamento que conflita com as condições desiguais entre homens e mulheres que caracterizam o trabalho nos canaviais e o trabalho rural, em geral.

Quanto ao estranhamento do trabalho, que tem origem nas contradições entre capital e trabalho, a impossibilidade de as bituqueiras imprimirem ao objeto do trabalho uma configuração ideada (ação teleológica), elas definem a si mesmas como trabalhadoras 'melhores' e 'mais fortes' que os homens. Elas seguem as ordens dos fiscais e as normas da empresa, já os homens estão mais dispostos a questionar e fazer greve. Por conta da necessidade de sobrevivência de si e do sustento da família, elas lidam com a degradação do trabalho explicando que os filhos terão mais oportunidades do que elas. Com certa altivez, essas trabalhadoras se veem em condições de vida mais favoráveis que suas mães e avós. $\mathrm{O}$ reconhecimento do papel do trabalho em suas vidas ocorre de forma conflituosa: mais independência versus mais problemas de saúde; mais oportunidades para os filhos versus não desejam que o seu trabalho seja exemplo para a escolha profissional dos filhos; conheceram pessoas de vários lugares e fizeram amizades versus a pressão dos fiscais; o medo dos riscos provocados pelo transporte precário, o desgosto e o nojo da comida fria e estragada.

$\mathrm{O}$ processo de estranhamento (no resultado e no ato de produção) do trabalho da bituqueiras mostra que o sistema do trabalho estranhado explora um modelo de satisfação de necessidades que se estende à esfera do consumo (ter) ao invés de realização (ser). As entrevistadas em nenhum momento falam que sonharam em ser bituqueiras. Elas também não esperam muito dessa ocupação, pois sofrem os preconceitos da sociedade, de outras mulheres, dos colegas homens, e sabem que significam muito pouco para a empresa. As entrevistadas não falam em nenhum momento da entrevista sobre a conexão entre o seu trabalho e o resultado do produto comercializado pela empresa. Elas explicam que esse é o trabalho que elas conseguem, e cujo salário lhes garante minimamente uma vida com algumas regalias: geladeira nova, televisão, comprar coisas de uso pessoal sem ter que pedir dinheiro para o marido, manter os filhos na escola. Elas mostram certa compreensão acerca dos problemas com o endividamento. Algumas falam de colegas que não souberam usar o dinheiro e gastaram tudo. Elas sabem que o dinheiro de uma safra tem que permitir sobreviver até a próxima safra.

Os resultados mostram que essas trabalhadoras mobilizam diferentes estratégias individuais que se tornam a base para um sistema social de defesa: medo da demissão devido às poucas opções de trabalho locais para a mulher com baixa qualificação e à necessidade de sobrevivência; ansiedade frente aos riscos gerados por uma atividade laboral que causa sofrimento físico e mental; angústia e raiva ao lidar com desigualdades nas questões de gênero; valorização do prazer de adquirir produtos vis-à-vis o impossível prazer de um trabalho libertador; e, busca de sentido para a sua existência vis-à-vis a crueldade da estigmatização e o "nojo social", a relação com a família e amigos.

Organizações Rurais \& Agroindustriais, Lavras, v. 19, n. 1, p. 31-46, 2017 
Quanto às sugestões para futuros estudos com esta temática, sugere-se ampliar o público pesquisado, a utilização de outras técnicas de coletas de dados, além da entrevista, e a incursão do pesquisador no local de trabalho. Na presente pesquisa, as entrevistas foram realizadas fora do local de trabalho, isso pode fazer com que as entrevistadas tenham se sentido mais seguras para abordar temáticas que não se sentiriam à vontade para tratar no espaço de trabalho, porém, o contato do pesquisador com esse espaço poderá ampliar os resultados. A pesquisa em regiões em que a mecanização da colheita de cana já é amplamente praticada pode mostrar outras estratégias de defesa.

$\mathrm{O}$ artigo mostra que a tríade conceitual utilizada na pesquisa oferece uma compreensão das relações interníveis para o estudo do trabalho: estratégias de defesa dos trabalhadores, sistemas coletivos de defesa, processos da gestão empresarial e processos socioeconômicos. Para lidar com o estranhamento de um trabalho que a sociedade não valoriza e que desperta nojo; com os processos de habituação que reduzem as alternativas de trabalho, impõem condições precárias e elevado grau de controle nas poucas alternativas existentes de trabalho, portanto de sobrevivência; as bituqueiras constroem defesas a partir de múltiplas imagens de si mesmas, isso lhes permite suportar um trabalho que se apresenta como insuportável. Elas são sobreviventes, para além da falta de oportunidades; são mulheres vencedoras, que superam quaisquer dificuldades; são mulheres fortes, capazes de fazer todo o serviço que um homem faz; mulheres livres, ao menos do ponto de vista financeiro, o que lhes garante relativa autonomia; exercem um trabalho digno, ainda que desperte o nojo social.

\section{AGRADECIMENTOS}

Esta pesquisa foi realizada com o apoio financeiro do Conselho Nacional de Desenvolvimento Científico e Tecnológico - CNPQ.

\section{REFERÊNCIAS}

ALVES, F. Por que morrem os cortadores de cana? Saúde e Sociedade, São Paulo, v. 15, n. 3, set./dez. p. 90-98, 2006.

ANTUNES, R. Adeus ao trabalho? Ensaio sobre as metamorfoses a centralidade do mundo do trabalho. Campinas: Ed. UNICAMP, 1995. 200 p. 2009. $261 \mathrm{p}$.

Os sentidos do trabalho. São Paulo: Boitempo,
BOCCHINI, B. Estudo mostra condições precárias de trabalho nos canaviais paulistas. EcoDebate, Mangariba, jan. 2011. Disponível em: <http://agenciabrasil.ebc. com.br/noticia/ 2011-01-05/estudo-mostra-condicoesprecarias-de-trabalho-nos-canaviais-paulistas $>$. Acesso em: 23 out. 2013.

BRAVERMAN, H. Big business moves in on the farmer. Marxists Internet Archive, [S.1.], 1956. Disponível em: <http://www.marxists.org/history/etol/newspape/ amersocialist/amersoc_5602-a.ht>. Acesso em: 30 jun. 2014.

. Trabalho e capital monopolista. Rio de Janeiro:

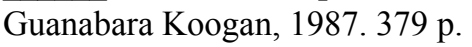

BURBACH, R.; FLYNN, P. Agroindústria nas Américas. Rio de Janeiro: Zahar, 1982. 284 p.

BURREL, G.; MORGAN, G. Sociological paradigms and organisational analysis: elements of the sociology of corporate. Farnham: Ashgate Publishing Limited, 2011. $448 \mathrm{p}$.

CARVALHO, C. O fim dos boias-frias. Jornal O Globo, Rio de Janeiro, 17 ago. 2013. Disponível em: $<$ http://oglobo.globo.com/economia/o-fim-dos-boiasfrias-9595711\#ixzz2r X7kqWGs>. Acesso em: 04 jan. 2013.

COLECTIONS: search colectiond. Philadelphia Museum of Art, Philadelphia, 2013. Disponível em: <http://www. philamuseum.org/collections/permanent/102974.html>. Acesso em: 23 out. 2013.

COSTA, P. F. F.; SILVA, M. S. Migração, sofrimento psíquico e estratégias defensivas "dos que migram" e "dos que ficam". Saúde Coletiva em Debate, Salvador, v. 1, n. 1, p. 15-30, out. 2011.

DEJOURS, C. A banalização da injustiça social. Rio de Janeiro: Ed. FGV, 2007. 160 p.

\section{$168 \mathrm{p}$.}

. A loucura do trabalho. São Paulo: Cortez, 2005.

DEJOURS, C. Itinerário teórico em psicopatologia do trabalho. In. DEJOURS, C.; ABDOUCHELI, E.; JAYET, C. Psicodinâmica do trabalho. São Paulo: Atlas, 1994. p. 119-145. 
DEJOURS, C.; ABDOUCHELI, E. Desejo ou motivação? A interrogação psicanalítica sobre o trabalho. In. DEJOURS, C.; ABDOUCHELI, E.; JAYET, C. Psicodinâmica do trabalho.. São Paulo: Atlas, 1994. p. 33-43.

DENZIN, N. K. The research act. New York: McGrawHill, 1977. 368 p.

DENZIN, N. K.; LINCOLN, Y. S. O planejamento da pesquisa qualitativa. Porto Alegre: Bookman, 2006. $432 \mathrm{p}$.

FREUD, A. O Ego e os mecanismos de defesa. Porto Alegre: Artmed, 2006. 124 p.

FREUD, S. O Ego e o Id. Rio de Janeiro: Imago, 1997. $81 \mathrm{p}$.

LOUREIRO, M. R. G. O controle do processo de trabalho na agricultura. Revista de Administração de Empresas, São Paulo, v. 21, n. 3, p. 29-34, jul./set. 1981.

LUKÁCS, G. As bases ontológicas do pensamento e da atividade do homem. Temas de Ciências Humanas, São Paulo, v. 13, n. 4, p. 1-18, 1978.

Para uma ontologia do ser social. São Paulo: Livraria Editora Ciências Humanas, 1979. 98 p.

MACIEL, M. R. A. et. al. Caracterização socioeconômica do trabalhador temporário da indústria canavieira em Lagoa da Prata, Minas Gerais, Brasil. Revista Sociedade \& Natureza, Uberlândia, v. 23, n. 2, p. 335-343, maio/ ago. 2011.

MARTINS, L. Fim do corte manual de cana deve fazer setor de máquinas crescer $25 \%$. Jornal Folha de São Paulo, São Paulo, 4 maio 2013. Disponível em: <http:// www1.folha.uol.com.br/mercado/2013/05/1271858-fimdo-corte-manual-de-cana-deve-fazer-setor-de-maquinascrescer-25.shtml>. Acesso em: 4 jan. 2014.

MARX, K. O capital. São Paulo: Abril Cultural, 1984. 287 p. $1 \mathrm{v}$.

MUSÉE D’ORSAY. Paris. Disponível em: < http://www. musee-orsay.fr/en/>. Acesso em: 23 out. 2013.
OLIVEIRA, J. N.; MENDES, A. M. Sofrimento psíquico e estratégias defensivas utilizadas por desempregados: contribuições da psicodinâmica do trabalho. Temas em Psicologia, Ribeirão Preto, v. 22, n. 2, p. 389-399, dez. 2014.

PATTON, M. Q. Qualitative research \& evaluation methods. Newbury Park: Sage Publications, 1990. 532 p.

ROSA, L. A.; NAVARRO, V. L. Trabalho e trabalhadores dos canaviais: perfil dos cortadores de cana da região de Ribeirão Preto (SP). Cadernos de Psicologia Social do Trabalho, São Paulo, v. 17, n. 1, p. 143-160, 2014.

SADER, E. A centralidade do trabalho. Revista Carta Maior, Porto Alegre, mar. 2011. Disponível em: <http:// www.cartamaior.com.br/?/Blog/Blog-do-Emir/Acentralidade-do-trabalho/2/23648>. Acesso em: 4 jan. 2014.

SANTOS, A. M. Mulheres canavieiras: as singularidades do trabalho realizado pelas "bituqueiras" no agronegócio sucroalcooleiro no município de Itaberaí-GO. Revista Pegada, Presidente Prudente, v. 15, n. 2, p. 95-114, dez. 2014.

SELIGMANN-SILVA, E. Trabalho e desgaste mental. São Paulo: Cortez, 2011. 624 p.

SENADO FEDERAL. Direitos humanos: a escravidão que precisa ser abolida. Em Discussão, ano 2, n. 7, p. 1-78, maio 2011.

SILVA, M. A. de M. O trabalho oculto nos canaviais paulistas. Revista Perspectivas, São Paulo, v. 39, p. 1146, jan./jun. 2011.

"Sabe o que é ficar borrado no eito da cana?"

Estudos Sociedade e Agricultura, Rio de Janeiro, v. 21, n. 2, p. 359-391, 2013.

SILVERMAN, D. Interpretação de dados qualitativos: métodos para análise de entrevistas, textos e interações. Porto Alegre: Artmed, 2009. 376 p.

VARDA, A. Os respigadores e a respigadora: documentário. França: FRA, 2000. Filme (82 min), color. 